\title{
PENGARUH PEMBERIAN TOKEN EKONOMI TERHADAP MOTIVASI BELAJAR SISWA SEKOLAH DASAR
}

\author{
Muriyawati, \& Faridah Ainur Rohmah \\ Fakultas Psikologi \\ Universitas Ahmad Dahlan \\ Jalan Kapas No. 9 Yogyakarta \\ Email : muri_wati@yahoo.com
}

\begin{abstract}
This research aims to know the effectiveness of the methods of granting token economy on children's learning motivation of students in fourth grade elementary school. This research used a method of experimentation with pretest-posttest design control group design. The measuring instruments used in the study of behaviour checklist, which is a tool of observation in the form of a list containing the numbers of subjects and behaviours-behaviours that are expected to arise during research.

A subject of study as many as 39 graders four state elementary school jongkang, sleman, namely 17 students referred to group of experimen and 22 students the control group. Age child was in range 9-10 years. The data of research was analyzed used technique analsis uji-t, namely paired sample t-test and independent sample t-test.

T-test analysis results paired sample t-test on the pretest and posttest data experimental group $t$ value $=-4,208$ with $p=0.001$ ( $p<0.01)$, it means the method token economy effect of positive learning motivation of students. Furthermore, the results of the analysis of test-t independent samples $t$-test using gain score on data group posttest experimental and control group showed the value of $t=3,073$ with $p=$ $0,004(p<0.01)$, it means that groups have a change of learning motivation is higher compared to the control group.

The conclusions of this research showed that the method token economy can affect the learning motivation of students, particular interest in learning, concentration of lessons in learning, persistence, and attention to the lesson.
\end{abstract}

Keywords: elementary school students learning Motivation, the token economy

\begin{abstract}
ABSTRAK
Penelitian ini bertujuan untuk mengetahui efektifitas pemberian metode token ekonomi terhadap motivasi belajar siswa pada anak kelas empat Sekolah Dasar. Metode yang digunakan adalah metode eksperimen dengan design pretest-posttest control group design. Alat ukur yang digunakan dalam penelitian berupa behaviour
\end{abstract}


checklist, yaitu alat observasi yang berupa daftar yang berisi nomor-nomor subjek dan perilaku-perilaku yang diharapkan muncul selama penelitian. Subjek penelitian sebanyak 39 siswa kelas empat Sekolah Dasar Negeri Jongkang, Sleman, yaitu 17 siswa termaksud kelompok ekperimen dan 22 siswa kelompok kontrol. Usia anak dalam rentang 9-10 tahun. Data yang diperoleh dari penelitian ini dianalisis menggunakan teknik analsis uji-t, yaitu paired sample t-test dan independent sample t-test. Hasil analisis uji-t paired sample t-test pada data pretest dan posttest kelompok eksperimen nilai $\mathrm{t}=-4,208$ dengan $\mathrm{p}=0,001(\mathrm{p}<0,01)$, artinya metode token ekonomi berpengaruh positif terhadap motivasi belajar siswa. Selanjutnya, hasil analisis uji-t independent sample t-test dengan menggunakan gain score pada data posttest kelompok eksperimen dan kelompok kontrol menunjukan nilai $\mathrm{t}=3,073$ dengan $\mathrm{p}=$ $0,004$ ( $\mathrm{p}<0,01)$, artinya kelompok ekperimen memiliki perubahan motivasi belajar yang lebih tinggi dibandingkan dengan kelompok kontrol. Kesimpulan dari penelitian ini menunjukan bahwa metode token ekonomi dapat mempengaruhi motivasi belajar siswa, khususnya minat dalam belajar, konsentrasi terhadap pelajaran, ketekunan dalam belajar, dan perhatian terhadap pelajaran.

Kata kunci: Motivasi belajar siswa sekolah dasar, token ekonomi

\section{Pendahuluan}

Sekolah Dasar adalah sarana proses pembelajaran awal pendidikan ketika seorang anak berusia tujuh tahun yang telah mengikuti program pendidikan usia dini dan pendidikan kanak-kanak. Sekolah Dasar juga merupakan sarana pendidikan bagi setiap anak sebagai tempat untuk memperoleh ilmu pengetahuan dan sebagai langkah awal pendidikan sebelum melanjutkan ke jenjang pendidikan yang lebih tinggi sehingga tercapainya suatu cita-cita. Menurut Munandar, masa anak sekolah diawali dengan tercapainya kematangan bersekolah, dan seorang anak dapat dikatakan matang untuk bersekolah apabila anak telah mencapai kematangan baik fisik, intelektual, moral maupun sosial (Kasiram, 2003).

Ketika proses belajar mengajar berlangsung di sekolah sering kali tenaga pendidik atau guru berhadapan dengan situasi masalah belajar mengajar. Siswa yang mengobrol di kelas ketika guru sedang menerangkan pelajaran adalah salah satu contoh masalah yang sering ditemukan dan biasa terjadi ketika proses belajar mengajar berlangsung. Seringkali juga tenaga pendidik berhadapan dengan siswa yang prestasi akademiknya bermacam-macam, ada siswa yang prestasi akademiknya baik dan siswa yang prestasi akademiknya kurang baik. Hal 
ini tentu bukan semata-mata siswa tersebut dilatarbelakangi dengan IQ yang tinggi atau rendah, tetapi juga dibarengi dengan ada tidaknya motivasi dalam diri siswa untuk belajar sehingga mencapai prestasi yang maksimal.

Motivasi belajar adalah keseluruhan daya penggerak di dalam diri siswa yang menimbulkan kegiatan belajar dan yang memberikan arah pada kegiatan belajar, sehingga tujuan yang dikehendaki oleh subjek belajar itu dapat tercapai (Sardiman, 2011). Menimbulkan motivasi belajar siswa di sekolah diperlukan adanya peran guru dalam proses interaksi kegiatan belajar mengajar di kelas, karena dengan adanya proses interaksi belajar mengajar diharapkan mampu memberikan dan mengembangkan motivasi belajar siswa agar melakukan kegiatan belajar secara optimal.

Seorang pelajar yang baik bukan hanya dilihat dari kehadirannya setiap hari di sekolah, tetapi harus memiliki motivasi belajar yang menjadikan dirinya aktif dalam proses belajar. Memperhatikan dan mendengarkan pejelasan guru ketika menerangkan pelajaran di kelas, mengerjakan tugas sekolah atau rumah, bertanya kepada guru tentang hal yang belum dipahami, mengemukakan pendapatnya di kelas, dan melakukan diskusi kelompok dengan temantemannya, Namun pada kenyataanya tidak sedikit siswa yang masih kurang motivasi belajarnya, seperti halnya siswa yang lebih senang mengobrol di kelas ketika guru sedang menjelaskan pelajaran, malas membuat tugas di sekolah, perilaku mencontek ketika ulangan, dan tidak jarang juga siswa bermain di kelas walaupun guru di ruang kelas. Akibatnya tidak sedikit siswa yang mendapatkan nilai kurang memuaskan ketika mengerjakan tugas harian, ketika ulangan harian, dan ujian sekolah. Tidak sedikit pula siswa yang merasa tidak percaya diri bahkan iri hati ketika nilai yang tertinggi diumumkan namanya di kelas, dan siswa yang memilki nilai rendah hanya dapat mengagumi siswa yang mendapatkan nilai tertinggi tersebut.

Berdasarkan observasi yang dilakukan peneliti terhadap siswa di sekolah dasar negeri kabupaten Sleman bahwa terdapat siswa yang motivasi belajarnya masih kurang hal ini terlihat dari perilaku siswa ketika proses belajar berlangsung yaitu adanya siswa yang mengobrol dengan teman sebangku dan adanya siswa yang meletakkan kepalanya di atas meja ketika guru sedang menerangkan pelajaran di kelas, banyaknya siswa yang tidak mengerjakan pekerjaan rumah, tidak menyelesaikan atau menuntaskan tugas sekolah, bercanda atau mengobrol pada saat guru meminta siswa untuk mengerjakan tugas ketika guru tidak. Hasil observasi juga didukung oleh hasil wawancara dengan 
beberapa guru yang mengajar siswa kelas IV kabupaten Sleman, yang menyatakan bahwa siswa masih banyak yang tidak mengerjakan pekerjaan rumah dan menyelesaikan tugas sekolah, siswa yang senang mengobrol dengan teman sebangku, siswa yang tidak memperhatikan guru ketika menerangkan pelajaran di kelas. Akibatnya ketika ulangan harian dan ujian sekolah tidak sedikit siswa yang mendapatkan nilai kurang memuaskan.

Berdasarkan kenyataan di atas peran guru sungguh diperlukan untuk membangkitkan motivasi di dalam belajar bagi siswa sehingga hal itu dapat menumbuhkan kegairahan belajar sekaligus menjadi aktif dalam proses pembelajaran, karena apabila siswa yang termotivasi dalam belajarnya akan menghabiskan waktu dan usahanya untuk mengerjakan tugas yang diberikan oleh guru dengan serius, sebaliknya seorang siswa yang kurang motivasi dalam belajarnya tidak mau belajar secara maksimal.

Motivasi yang berasal dari kata "motif" diartikan sebagai daya upaya yang mendorong seseorang untuk melakukan sesuatu. Motif dapat dikatakan sebagai daya penggerak dari dalam dan di dalam subjek untuk melakukan aktivitas-aktivitas tertentu demi mencapai suatu tujuan. Berawal dari kata motif maka motivasi dapat diartikan sebagai daya penggerak yang telah menjadi aktif (Sardiman, 2011).
Memberikan motivasi kepada siswa, berarti sudah menggerakan siswa untuk bergerak melakukan sesuatu dalam belajar, sesuatu yang pada akhirnya menyebabkan subjek menjadikan belajar sebagai kebutuhan dalam hidup. Secara fisiologis belajar merupakan suatu proses perubahan dalam tingkah laku sebagai hasil dari interaksi dengan lingkungannya dalam memenuhi kebutuhan hidupnya (Slameto, 1991).

Motivasi belajar adalah kekuatan pendorong atau pengarah perbuatan belajar, pendorong dalam arti pemberi kekuatan yang memungkinkan perbuatan belajar dijalankan (Mujiman, 2008). Motivasi belajar diartikan sebagai kekuatan mental yaitu berupa keinginan, perhatian, kemauan atau cita-cita yang menjadi penggerak atau pendorong terjadinya perilaku belajar (Diyamti \& Mujiono, 2002).

Membangkitkan motivasi kepada siswa tidaklah mudah untuk itu diperlukan hubungan dan komunikasi yang baik dengan siswa dan memiliki kesanggupan yang kreatif untuk menguhungkan pelajaran dan motivasi belajar anak disekolah, sehingga siswa menjadi semangat untuk belajar hingga berhasil.

Ciri-ciri motivasi belajar menurut Anderson \& Faust (Adawiyah \& Widiana, 2009) adalah;

a. Minat dalam belajar 
Siswa yang memiliki motivasi belajar yang kuat akan menunjukan minat yang besar untuk terus belajar. Siswa akan terus tertarik dengan pelajaran-pelajaran yang diterimanya di sekolah dan selalu berusaha mempelajarinya kembali

b. Konsentrasi terhadap pelajaran

Konsentrasi yang penuh terhadap pelajaran yang sedang berlangsung di dalam kelas akan membawa pengaruh yang positif dalam mencapai hasil belajar. Siswa yang mempunyai motivasi belajar yang tinggi akan senantiasa memfokuskan atau mengkonsentrasikan pikirannya pada pelajaran di sekolah, konsentrasinya tidak terpecah pada hal-hal diluar sekolah.

c. Ketekunan dalam belajar

Ketekunan dalam belajar sangat berpengaruh terhadap pencapaian hasil belajar yang baik. Siswa yang memiliki ketekunan dalam belajar tidak mudah merasa putus asa ketika mendapat kegagalan dalam proses belajar. Siswa yang memiliki ketekunan dalam belajar biasanya dikategorikan memiliki motivasi belajar yang tinggi.

d. Perhatian terhadap pelajaran

Siswa yang memiliki motivasi belajar yang kuat selalu memusatkan perhatiannya pada pelajaran dan mengerjakan tugas-tugas yang diberikan dalam belajar. Siswa akan sebanyak mungkin memusatkan perhatian terhadap pelajaran yang sedag diterangkan oleh guru di dalam kelas.

Karakteristik motivasi belajar sangat penting dimiliki oleh setiap siswa dalam belajar dimana siswa harus memiliki ketekunan dalam menghadapi tugas, ulet menangani suatu masalah dan senang bekerja secara mandiri. Siswa yang memiliki motivasi belajar yang tinggi akan bosan pada tugas yang rutin dan akan mempertahankan pendapatnya terhadap hal-hal yang sudah diyakini sehingga dapat menyelesaikan masalahnya dengan tepat.

Sardiman (2011) menyebutkan bahwa ada dua macam motivasi dalam belajar yaitu motivasi intrinsik dan motivasi ekstrinsik. Motivasi instrinsik merupakan motif-motif yang menjadi aktif atau fungsinya tidak perlu diragsang dari luar, karena dalam diri setiap individu sudah ada dorongan untuk melakukakan sesuatu. Misalnya, seorang siswa melakukan kegiatan belajar setiap harinya tanpa menunggu adanya tugas rumah atau ulangan. Sedangkan motivasi ekstirnsik merupakan motif-motif yang aktif dan berfungsinya karena adanya rangsangan atau dorongan dari luar. Misalnya, seorang siswa belajar karena mengetahui besok akan ada ujian, dengan harapan akan mendapatkan nilai yang baik dan mendaptkan peringkat di kelas. 
Menurut Diyamti \& Mijiono (2002) ada lima fungsi motivasi belajar bagi siswa yaitu:

a. Menyadarkan pada kedudukan pada awal belajar, proses dan hasil akhir. Misalnya, setelah seseorang membaca suatu bab buku bacaan, dibandingkan dengan teman sekelasnya yang juga membaca bab tersebut, ia kurang berhasil menangkap isi, maka ia terdorong untuk membaca lagi.

b. Menginformasikan tentang kekuatan usaha belajar yang dibandingkan dengan teman sebaya. Misalnya, jika terbukti seorang siswa belum memadai, maka ia berusaha setekun temannya yang belajar dan berhasil.

c. Mengarahkan kegiatan belajar. Misalnya, setelah dia tahu bahwa dirinya belum belajar serius yang terbukti banyak besenda gurau maka ia akan mengubah perilaku belajarnya.

d. Membesarkan semangat belajar. Misalnya, jika ia telah menghabiskan dana belajar dan masih ada adik yang dibiayai orang tua, maka ia berusaha agar cepat lulus.

Menyadarkan tentang adanya perjalanan belajar dan kemudian bekerja yang bersinambungan, individu dilatih untuk menggunakan kekuatannya sedemikian rupa sehingga dapat berhasil.

Witherington dkk. (Mustaqim, 2004), mengatakan bahwa ada faktor-faktor serta kondisi-kondisi yang mempengaruhi atau mendorong perbuatan belajar seseorang yaitu; a) situasi belajar, b) Penguasaan alat-alat intelektual, c) latihan-latihan yang terpencar, d) penggunaan unit-unit yang berarti, e) latihan yang aktif, f) kebaikan bentuk dan sistem, g) efek penghargaan (reward) dan hukuman, h) tindakan-tindakan pendagosis, i) kapasitas dasar.

Hamalik (2002) mengatakan bahwa teknik memotivasi siswa dalam belajar harus berdasarkan kebutuhannya yaitu: pemberian penghargaan atau ganjaran, pemberian angka atau grade, keberhasilan dan tingkat aspirasi, pemberian pujian, kompetisi dan kooperasi, serta pemberian harapan. Pemberian hadiah atau pemberian token ekonomi yang dapat berupa peringkat huruf atau angka, tandatanda bintang, tanda benar, centang, hadiah idaman, dan lain-lain yang diberikan oleh guru untuk siswa adalah motivasi ekstrinsik yang dapat menumbuhkan dan meningkatkan motivasi belajar siswa di sekolah, hal ini juga berfungsi untuk memperkuat pendapat atau keyakinan siswa atas prestasi yang telah dicapai. Reward atau hadiah adalah akibat dari tigkah laku di mana hadiah bisa menyebabkan tingkah laku yang diberi hadiah itu lebih sering terjadi (Alwisol, 2004). Menurut Kartono dan Gulo, (2000) reward adalah ganjaran, upah, hadiah, pahala, yang merupakan konsekuensi positif yang mengikuti sebuah tindakan, imbalan yang diterima dengan menjalankan perilaku tertentu yang biasanya berfungsi sebagai penguat respon. 
Motivasi ekstirnsik merupakan motifmotif yang aktif dan berfungsinya karena adanya rangsangan atau dorongan dari luar. Pemberian hadiah atau pemberian token ekonomi yang dapat berupa peringkat huruf atau angka, tanda-tanda bintang, tanda benar, centang, hadiah idaman, dan lain-lain yang diberikan oleh guru untuk siswa adalah salah satu bentuk motivasi ekstrinsik yang dapat menumbuhkan dan meningkatkan motivasi belajar siswa di sekolah, hal ini juga berfungsi untuk memperkuat pendapat atau keyakinan siswa atas prestasi yang telah dicapai.

Pemberian hadiah atau reward dengan metode token ekonomi juga merupakan suatu alternatif untuk meningkatkan motivasi belajar siswa baik di sekolah maupun di rumah. Ketika siswa telah selesai melakukan kegiatan belajar dan mendapatkan hasil yang maksimal, kemudian usaha tersebut diberi penghargaan berupa pemberian suatu tanda yang menarik seperti bintang, prangko, replika dollar, stempel dan lain-lain yang tanda tersebut dapat ditukarkan dengan hadiah idaman atau yang diinginkan dapat menimbulkan perasaan senang serta adanya penghargaan dalam diri siswa, karena usaha yang sudah dijalankan mendapat respon yang baik dan sebagai positive reinforcement yang diberikan guru kepada siswa.

Pernyataan tersebut juga dijelaskan bahwa reward atau hadiah adalah akibat dari tigkah laku dimana hadiah bisa menyebabkan tingkah laku yang diberi hadiah itu lebih sering terjadi (Alwisol, 2004). Dalam hal ini diperlukan peran guru untuk membangkitkan motivasi belajar bagi siswa sehingga hal itu dapat menumbuhkan kegairahan belajar sekaligus membuat mereka aktif dalam proses pembelajaran baik di kelas atau di rumah.

Token ekonomi adalah salah satu metode atau cara untuk meningkatkan perilaku belajar pada siswa. Token ekonomi adalah pemberian satu kepingan (atau suatu tanda, satu isyarat) sesegera mungkin setiap kali setiap perilaku sasaran muncul. Kepingan-kepingan ini nantinya dapat ditukar dengan benda atau aktivitas pengukuh yang diinginkan subjek.

Reward atau token ekonomi merupakan salah satu bentuk penguatan positif (positive reinforcement). Menurut Syah (1999), token ekonomi adalah suatu sistem dalam modifikasi perilaku melalui penguatan positif (positive reinforcement) yang berasal dari dasar operant conditioning. Respon dalam operant conditioning, terjadi tanpa didahului stimulus, melainkan oleh efek yang ditimbulkan oleh reinforcer. Reinforcer itu sendiri sesungguhnya adalah stimulus yang dapat meningkatkan kemungkinan timbulnya sejumlah respon tertentu (Anita ddk, 2003). Penguat dikatakan sebagai reinforcement yaitu konsekuensi yang meningkatkan 
probabilitas bahwa suatu perilaku akan terjadi. yaitu frekuensi meningkat karena diikuti dengan stimulus yang mendukung (rewarding).

Menurut Martin \& Pear, (2003), sebelum menerapkan token ekonomi, perlu dirancang atau disiapkan langkah-langkahnya yaitu;

a. Menentukan perilaku target (deciding oln the target behavior)

Perilaku target akan ditentukan dari banyaknya individu dengan siapa individu itu bekerja, dengan menghitung jarak pendek dan jarak panjang perilaku sasaran yang ingin dicapai dari masalah perilaku yang ditemukan.

b. Pengambilan data dasar (taking baselines)

Pengambilan data dasar (baselines) dilakukan sebelum memulai prosedur berikutnya. Data perilaku subjek harus diperoleh sebelum memulai token ekonomi. Hal ini dilakukan karena memungkinan subjek mendapatkan kepuasan yang diperoleh dari kebaikan dan kelebihan penerapan token ekonomi yaitu tidak memerlukan waktu, tenaga, dan biaya. Setelah program dijalanakan, data yang diperoleh dibandingkan dengan data dasar (baselines) yang menentukan efektivitas program.

c. Memilih pengukuh cadangan (Selecting backup reinforcers)

Memilih kembali metode yang pada dasarnya sama yaitu untuk memperkuat perilaku. Tetap di dalam pikiran, bagaimana cara yang pernah dilakukan, bahwa sebuah sistem token ekonomi yang pada umumnya merupakan pengukuh yang praktis dan dapat digunakan, karena token ekonomi tidak menjadi batas bagi mereka. Dimana token tersebut diberikan setelah respon yang diinginkan muncul

d. Memilih jenis token ekonomi yang digunakan (Selecting the type of token economy to use).

Tanda dapat diambil disalah satu bentuk yang telah diasumsikan. Poker chips yang sering digunakan, cek pribadi, tanda pada grafik di dinding, atau catatan dalam buku, bintang atau perangko yang ditempel dalam buku dan masih banyak lagi token ekonomi yang mungkin sesuai dengan kebutuhan subjek.

e. Mengidentifikasi bantuan yang tersedia (identifying available help)

Bantuan dari orang lain mungkin tidak penting dalam token ekonomi yang kecil seperti kelas, tetapi pasti membutuhkan bantuan terutama pada tahap-tahap awal program. Dalam pemberian token ekonomi dengan skala yang besar, bantuan seperti fasilitas psikiatri sangat penting. Ada beberapa sumber yang dapat memberikan bantuan: (a) orang-orang yang sudah ditugaskan untuk bekerja dengan klien (guru pembantu, pembantu perawat, asisten pengajar); (b) relawan (anggota organisasi 
sipil dan kelompok-kelompok aksi masyarakat); (c) perilaku individu dalam lembaga, dan (d) anggota atau peserta token ekonomi itu sendiri. Dalam beberapa kasus, klien telah mengajarkan untuk memberikan token ekonomi kepada diri mereka sendiri sesuai pada perilaku yang diharapkan.

f. Memilih lokasi atau tempat (choosing the locations)

Tidak ada lokasi khusus untuk token ekonomi, rancanan token ekonomi yang bagus dikarenakan memiliki sedikit atau tidak ada pilihan lokasi. Beberapa lokasi lebih baik dari pada yang lain, namun, tergantung pada pertimbangan jenis token ekonomi.

Menurut Soekadji (1983), agar efektif penerapan token ekonomi perlu memenuhi beberapa aturan dan pertimbangan yaitu:

a. Hindari penundaan

Pemberian pengukuhan dilakukan seketika setelah perilaku yang diharapkan muncul. Meskipun hadiah atau reward yang sebenarnya baru dapat diberikan kemudian, namun kepingan-kepingan ini dapat mewakili, menandai, syarat, ataupun simbol, bahwa sebagai hadiah idaman telah ada ditangan subjek.

b.Berikan kepingan secara konsisten

Pada program ini setiap kali perilaku yang telah dilaksanakan, diberi imbalan kepingan secara konsisiten agar dapat mempercepat peningkatan perilaku sasaran.
c.Memperhitungkan kuantitas

Perlu direncanakan agar banyaknya kepingan yang akan diterima cukup untuk ditukar dengan pengukuh idaman

d.Persyaratan hendaknya jelas

Aturan yag jelas mudah diikuti. subjek diajak diskusi mengenai aturan-aturan dan persyaratan untuk memperoleh kepingan

e. Pilih pengukuh yang macam dan kualitasnya memadai.

Mencocokan macam dan kualitasnya dengan situasi dan kondisi subjek.

f. Pemasaran pengadaan pengukuh idaman

Pemasaran pengukuh idaman perlu memperhitungkan hukum penawaran dan permintaan. Makin banyak permintaan suatu aktivitas, makin dapat dipasang harga tinggi nilai tukarnya.

g. Kombinasikan pemberian kepingan dengan pengukuh sosial positif

Melatih mengelola subjek untuk memberi penghargaan pada diri subjek, agar subjek dapat berpindah dari pengukuh kepingan ke pengukuh sosial.

h. Perhitungkan efeknya kepada orang lain. Teman sebaya, saudara kandung akan iri bila salah satu diantara mereka mendapat perlakuan istimewa, untuk itu diusahakan agar mereka ikut membantu subjek memperoleh kepingan. 
i. Perlu pesetujuan berbagai pihak

Perlu izin pelaksanaan dari orang tua, guru, dan orang-orang yang ditumpangi dalam mengelola program. Maksudnya sebelum menjalankan program adanya izin dari pihak terkait seperti kepala sekolah, guru, orang tua, manager, supervisior dan lain-lain agar dapat bekerjasama ketika menjalankan program.

j. Perlu kerjasama subjek

Pentingnya komunikasi dengan subjek tentang aturan main sehingga subjek setuju pada program yang akan dilaksanakan.

k. Perlu latihan bagi pelaksana

Perlu mendapatkan latihan-latihan dan pengetahuan yang diperlukan bila pelaksana program diserahkan kepada guru, orang tua, atau orang lain. Individu hendaknya memberikan penjelasan dengan baik proses menjalankan program metode token ekonomi kepada guru dan orang tua.

1. Perlu pencatatan

Pencatatan cermat mengenai frekuensi perilaku-sasaran dan perilaku lain perlu dilakukan. Maksudnya, diperlukan pencatatan secara cermat dan teliti terhadap banyaknya perilaku yang diharapkan.

$\mathrm{m}$. Kombinasi dengan prosedur lain

Program token ekonomi dapat dikombinasikan dengan prosedur lain seperti denda dan penyisihan.

n. Follow-up : penunda pengukuhan

Bila program kepingan telah berhasil meningkatkan perilaku sedangkan pengukuh sosial belum dapat menggantikan keseluruhan program keping, maka perlu diadakan latihan penyapihan dengan mengurangi nilai token.

Berdasarkan uraian di atas dapat dilihat bahwa penghargaan atau hadiah (reward) merupakan faktor-faktor yang diasumsikan berpengaruh terhadap terjadinya peningkatan motivasi belajar siswa akan tetapi dugaan tersebut masih bersifat teori dan memerlukan bukti secara nyata. Oleh karena itu peneliti tertarik untuk meneliti pengaruh pemberian token ekonomi terhadap motivasi belajar siswa sekolah dasar.

Hipotesis dalam penelitian ini adalah ada peningkatan motivasi belajar siswa yang diberikan token ekonomi, dengan siswa yang tidak diberikan token ekonomi ketika peroses belajar berlangsung. Siswa yang diberikan token ekonomi mempunyai motivasi belajar lebih tinggi dari pada siswa yang tidak diberikan token ekonomi.

\section{Metode Penelitian}

Subjek penelitian dalam penelitian ini adalah siswa sekolah dasar (SD) yang duduk dikelas IVA dan IVB SDN Jongkang semester satu tahun ajaran 2012/2013, kecamatan Ngaglik, Sleman, Yogyakarta.

Pengumpulan data dalam penelitian ini menggunakan observasi dengan metode behavior checklist. Behavior checklist adalah alat observasi yang berupa daftar yang berisi nomor subjek dan perilaku-perilaku yang 
diharapkan muncul. Checklist dimaksudkan untuk mensistematisasi catatan observasi. Behavior checklist ini digunakan sebagai analisa untuk mengetahui berbagai perilaku yang muncul selama penelitian. Lembar ini terdiri dari beberapa kolom yang berisikan tanda checklist pada nomor kursi siswa dan indikator-indikator perilaku motivai belajar yaitu, minat dalam belajar, konsentrasi terhadap pelajaran, ketekunan dalam belajar, dan perhatian terhadap pelajaran. Behaviour checklist digunakan sebagai alat untuk mengukur motivasi belajar siswa. Semua aktivitas siswa yang dilihat berkaitan dengan kegiatan siswa baik di dalam kelas maupun di rumah. Aturan pemberian skor adalah setiap perilaku yan muncul diberi skor satu, sedangkan setiap perilaku yang tidak muncul diberi skor nol.

Analisis data dalam penelitian ini adalah metode statistik parametrik. Teknik analisis yang digunakan dalam penelitian ini adalah uji perbedaan (uji-t) yaitu paired sample t-test dan independent sample t-tes. Paired sample t-tes digunakan untuk menguji perbedaan rata-rata (mean) antara hasil pretest dan postest pada masing-masing kelompok (kelompok ekperimen dan kelompok kontrol). Independent sample t-test digunakan untuk menguji perbedaan rata-rata (mean) skor hasil posttest dikurangkan dengan hasil pretest (gainscore) antara kelompok eksperimen dengan kelompok kontrol. Metode analisis yang digunakan dalam penelitian ini menggunakan bantuan program komputer SPSS 17.0 for Windows.

\section{Hasil dan Pembahasan}

Suatu penelitian komparatif (perbedaan) kuatitatif dengan analisis statistik parametrik sebelum diadakan uji hipotesis terlebih dahulu ada persyaratan yang harus dipenuhi yaitu distribusi sampel harus normal dan mempunyai variansi skor yang homogen (setara).

a. uji normalitas

uji normalitas menggunakan One Sample Kolmogorov Smirnov Test. Kaidah uji signifikan adalah $\mathrm{p}>0,05$, maka tidak ada perbedaan antara skor subjek sampel penelitian dan sebaran skor subjek pada populasi (sebaran dikatakan normal) dan sebaliknya apabila $\mathrm{p}<0,05$ maka sebaran dinyatakan tidak normal. Analisis data untuk kelompok eksperimen pada pretest menghasilkan Kolmogrof-Smirnov $Z$ adalah 0,692 dengan $\mathrm{p}=0,724$ dan untuk kelompok eksperimen pada posttest menghasilkan Kolmogrov-Smirnov $Z$ adalah 0,525 dengan $\mathrm{p}=0,946$. Sedangan untuk kelompok kontrol pada pretest menghasilkan KolmogrofSmirnov $Z$ adalah 0,708 dengan $\mathrm{p}=0,698$ dan untuk kelompok kontrol pada posttest menghasilkan Kolmogrof-Smirnov $Z$ adalah 
0,757 dengan $\mathrm{p}=0,615$. Berdasarkan hasil analisis ini, maka dapat dikatakan bahwa antara siswa kelompok eksperimen dan kelompok kontrol mempunyai skor yang berdistribusi normal.

b. Uji homogenitas

Uji homogenitas menggunakan One Way Anova Test of Homogeneity of Variances dengan kaidah jika p>0,05 maka variansi pada tiap kelompok data adalah sama (homogen). Jika $\mathrm{p}<0,05$, maka variansi pada tiap kelompok data adalah tidak sama (tidak homogen). Pada penelitian ini hasil pengujian homogenitas pada data pretest, menunjukan bahwa nilai levene statistic $=1,395$ dan $\mathrm{p}=$ $0,244(\mathrm{p}>0,05)$ artinya tidak signifikan, maka berdasarkan hasil analisis ini dapat disimpulkan bahwa tidak ada perbedaan variansi kelompok (homogen). Hasil komputerisasi dapat dilihat pada lampiran.

Pengujian hipotesis yang digunakan untuk menganilisis data dalam penelitian ini adalah metode statistik parametrik. Teknik analisis yang digunakan dalam penelitian ini adalah uji perbedaan (uji-t) yaitu paired sample t-test dan independent sample t-tes. Paired sample $t$-tes digunakan untuk menguji perbedaan rata-rata (mean) antara hasil pretest dan postest pada masing-masing kelompok (kelompok ekperimen dan kelompok kontrol). Independent sample t-test digunakan untuk menguji perbedaan rata-rata (mean) skor hasil posttest dikurangkan dengan hasil pretest (gainscore) antara kelompok eksperimen dengan kelompok kontrol.

\section{a. Paired Sample t-test}

Paired sample t-test digunakan untuk menguji perbedaan rata-rata (mean) antara hasil pretest dan posttest pada masing-masing kelompok yaitu kelompok eksperimen dan kelompok kontrol.

Hasil analisis uji-t yaitu paired sample t-test pada kelompok ekperimen diperoleh nilai $\mathrm{t}=-4,208$ dan $\mathrm{p}=0,001(\mathrm{p}<0,05)$ artinya sangat signifikan, sedangkan pada kelompok kontrol diperoleh dengan nilai $\mathrm{t}=-349$ dan $\mathrm{p}=0,731 \quad(\mathrm{p}>0,05)$, artinya tidak signifikan. Berdasarkan hasil kedua analisis tersebut, maka dapat disimpulkan bahwa hipotesisi peneliti yang menyatakan metode token ekonomi berpengaruh positif terhadap motivasi belajar siswa, dapat diterima.

\section{b. Independent Sample t-test}

Independent Sample t-test digunkan untuk menguji signifikansi beda rata-rata dua kelompok. Independent Sample t-test pada kelompok eksperimen dan kelompok kontrol menggunakan gain score. Gain score merupakan selisih nilai sebelum diberi perlakuan dan sesudah diberi perlakuan.

Berdasarkan hasil analisis uji-t diperoleh nilai $\mathrm{t}=3,073$ dengan skor Sig. (2tailed $)=0,004$, maka dapat dikatakan bahwa terdapat perbedaan motivasi belajar yang 
sangat signifikan antara kelompok eksperimen dan kelompok kontrol. Hasil nilai rata-rata (mean) motivasi belajar pada kelompok eksperimen menunjukan nilai $\mathrm{M}=1,6824$ dan pada kelompok kontrol menunjukan nilai $\mathrm{M}=$ 0,1136, artinya ada perbedaan yang terjadi antara kelompok eksperimen dan kelompok kontrol yang menggunkan token ekonomi dengan yang tidak. Hal ini juga dapat dilihat dengan melihat rata-rata kelompok eksperimen sebelum diberikan perlakuan sebesar 6,4206 dan sesudah diberikan perlakuan sebesar 8,1029. Nilai ini menujukan bahwa ada peningkatan motivasi belajar pada siswa pada kelompok eksperimen.

Dari hasil analisis data dengan menggunakan paired sample t-test yang diperoleh dengan nilai $-4,208$ dan $\mathrm{p}=0,001$ membuktikan bahwa motivasi belajar siswa pada kelompok ekspererimen yang diberikan metode token ekonomi dalam proses belajar lebih tinggi dibandingkan dengan kelompok kontrol yang tidak diberikan metode token ekonomi, yaitu dengan nilai -0,349 dan $\mathrm{p}=0,731$. Artinya penggunaan metode token ekonomi efektif dalam proses belajar siswa baik di kelas maupun di rumah. Selain itu, nilai rata-rata (mean) kelompok eksperimen sebelum diberikan perlakuan (pretest) sebesar 6,4206 dan sesudah diberikan perlakuan (posttest) sebesar 8,1029, nilai ini menunjukan bahwa ada peningkatan motivasi belajar siswa kelas IVB pada kelompok eksperimen.

Token ekonomi yang dimaksud dalam penelitian ini adalah pemberian stempel sebagai tanda sementara, dimana tanda tersebut dikumpulkan dan dapat ditukarkan dengan hadiah atau pengukuh idaman. Token ekonomi sendiri pada dasarnya merupakan upaya untuk mendorong siswa melaksanakan perilaku belajar siswa di kelas. Hal ini didukung oleh penelitian yang dilakukan oleh Triplett (Budisetyani, 2005) yang mengatakan bahwa individu akan menunjukan performa yang lebih baik dengan adanya penghargaan atau kehadiran orang lain. Selain itu Kazhim (2010) mengatakan bahwa hadiah adalah wujud penghargaan dan dukungan atas sebuah prestasi dan perilaku yang baik yang dimiliki seorang anak, hadiah juga merupakan sebuah simbol, dengan hadiah anak akan merasakan bahwa perilaku dan prestasi yang diraih adalah suatu yang harus dipertahankan.

Peneliti memberikan stempel bergambar animasi (angy bird) warna merah dimana stempel tersebut akan distempelkan pada poster lipat berwarna biru dan kuning apabila siswa melaksanakan perilaku belajar yang sudah tertulis dalam poster lipat dan untuk pemberian token sendiri menjadi dua tahap. Tahap pertama di minggu pertama jumlah stempel yang harus dikumpulkan siswa sebanyak 40 dan 80 buah stempel 
dengan total keseluruhan 120 stempel dalam satu minggu. Pada tahap kedua di minggu kedua jumlah stempel yang harus dikumpulkan siswa tidak berbeda yakni sebanyak 40 dan 80 buah stempel dengan total keseluruhan 120 stempel, namun pemberian atau perolehan poin di minggu kedua tidak semudah seperti di minggu pertama, karena adanya pengurangan poin dalam setiap perilaku dengan perolehan total stempel yang harus di dapatkan sebanyak 120 stempel dan apabila subjek tidak melaksanakan perilaku belajar yang diinginkan akan dikenakan denda berupa pengurangan satu poin dari jumlah poin yang suda dikumpulkan.

Dari hasil observasi dan analisis yang dilakukan selama diberikannya perlakuan berupa token ekonom, siswa mengalami peningkatan perilaku dalam proses belajar di kelas maupun di rumah. Hal ini pun diperkuat dengan penelitian Indrizati (2002), yang menyatakan bahwa metode tabungan kepingan itu efektif pada seluruh tingkat usia. Pada situasi ketika kontrol yang sangat ketat dibutuhkan maka metode tabungan kepingan menjadi metode intervensi yang baik. Winto, probowati dan Atmadji (2005) juga mengatakan bahwa teknik terbaik bagi peningkatan dan pemeliharaan perilaku ialah penerapan prosedur pengukuh positif. Suatu proses pemberian stimulus (benda atau kejadian) sebagai konsekuensi suatu perilaku dan berhasil menyebabkan perilaku tersebut meningkat, berulang atau terpelihara disebut pengukuhan positif (positive reinforcement).

\section{Kesimpulan}

Berdasarkan hasil penelitian yang didapat setelah melakukan analisis data dengan menggunakan uji-t yaiti paired sample t-test dan independent sample t-test, maka dapat diambil kesimpulan bahwa metode token ekonomi dapat meningkatkan atau berpengaruh positif untuk meningkatkan motivasi belajar siswa dibandingan yang tidak mengguakan metode token ekonomi, sehingga ada perbedaan motivasi belajar yang sangat signifikan atara kelompok eksperimen dengan kelompok kontrol. Penggunaan metode token ekonomi pada kelompok eksperimen sangat signifikan dalam meningkatkan motivasi belajar siswa.

\section{Saran}

Hasil penelitian ini diharapkan dapat memberikan informasi kepada tenaga pendidik, dan orang tua bahwa metode pemberian token ekonomi dapat meningkatkan motivasi belajar anak baik di sekolah maupun di rumah.

Untuk peneliti selanjutnya yang tertarik untuk meneliti penggunaan metode token ekonomi khususnya di dunia pendidikan hendaknya lebih dapat mempersiapkan prosedur atau cara yang akan dijalankan agar lebih matang dan lancar, seperti mempersiapkan alat, bahan, dan waktu yang 
tepat. Peneliti juga harus mengkoordinasikan dalam penggunaan token ekonomi dengan guru yang bersangkutan, agar penelitian dapat berjalan dengan lancar. Serta disarankan untuk penelitian selanjutnya hendaknya menggunakan cara atau metode lain untuk meningkatkan motivasi belajar siswa.

\section{DAFTAR PUSTAKA}

Adawiyah, P.R. Widiana, S.H. 2009. Motivasi Belajar Dalam Mempelajari Agama Islam Ditinjau Dari Metode Pembelajaran. Jurnal Psikologi Vol.II No.2. 151-165

Ahmadi, A \& Supriono, W. 1991. Psikologi Belajar. Jakarta: PT Rineka Cipta.

Alwilsol. 2004. Psikologi Kepribadian. Malang: UMM Press.

Diyamti \& Mujiono. 2002. Belajar dan pembelajaran. Jakarta: PT Rineka Cipta.

Hamalik, O. 2002. Psikologi Belajar dan Mengajar. Bandung: Sinar Baru Algensindo Offest.

Mahendra, A. \& Ma'mun, A. 1998. Teori Belajar dan Pembelajaran Motorik. Bandung: CV Andira.

Makmun, A. S. 2003. Psikologi Kependidikan Perangkat Sistem Pengajaran Modul. Bandung: PT Remaja Rosdakarya.

Martin, G. \& Pear, J. 2003. Behavior Modification: What It Is and How To Do It. United States of America: Pearson Prentice Hall.

Miltenberger, Raymon G. 2004. Behavior Modification: Principle and Procedures Third Edition. United States of America: Wadsworth.
Mujiman, H. 2006. Manajemen Pelatihan Berbasis Belajar Mandiri. Yogyakarta: Pustaka Pelajar.

Mustaqim. 2004. Psikologi Pendidikan. Semarang: Pustaka Pelajar.

Sardiman, A. M. 2011. Interaksi dan Motivasi Belajar Mengajar. Jakarta: PT Grafindo Persaja.

Slameto. 1991. Belajar dan Faktor-faktor yang Mempengaruhi. Jakarta: Rineka Cipta.

Syah, M. M.ed. 1999. Psikologi Belajar. Jakarta: PT Logos Wacana Ilmu.

Soekadji, Soetarlinah. 1983. Modifikasi Perilaku: Penerapan Sehari-hari dan Penerapan Profesional. Yogyakarta: Liberty.

Wahyuni, E. N. 2009. Motivasi Dalam Pembelajaran. Malang: UIN Malang Press. 